\title{
ANALISIS LITERASI MATEMATIKA PADA PENYELESAIAN SOAL CERITA SISWA KELAS V SEKOLAH DASAR
}

\author{
Yesika Simarmata $^{1}$, Nelly Wedyawati ${ }^{2}$, Anita Sri Rejeki Hutagaol ${ }^{3}$ \\ ${ }^{1,2,3}$ STKIP Persada Khatulistiwa Sintang, Jl. Pertamina, Sengkuang, Sintang \\ e-mail: ${ }^{1}$ simarmata.yesika@ gmail.com, ${ }^{2}$ nellywedyawati@ymail.com, \\ boruhutagaolbest@gmail.com
}

\begin{abstract}
There are still students who have not been able to read, count with addition, subtraction, multiplication or division well, students lack discipline in class in working on problems, lack of student interest in reading questions intensively and counting makes it difficult for students to solve math story problems. The research method used is qualitative-descriptive method and the form of research is descriptive. Data collection techniques using test techniques, observation techniques, and interview techniques. Data collection tools use test questions, observation sheets, and interview sheets. The results showed that only 1 of 16 students had a score of 51 in the category of predicate $C$ (enough) and 15 people with low ability with an average value of 9.5 in category D (less), overall the average value of VA class students at the completion of the story problem is 12 with the title $D$ (less), therefore the use of mathematical literacy in the solution of the story problem is still relatively low. The conclusion of the study is the mathematical literacy in solving story problems in the VA class at SDN 6 Sintang in the academic year 2019/2020 is still low because of the low ability of reading, writing and numerical ability, and the role of teachers and schools that are less supportive in learning mathematics literacy.
\end{abstract}

Keyword: Literacy, Mathematics, Solving, and Story Questions.

\begin{abstract}
Abstrak. Kesulitan siswa dalam menyelesaikan soal cerita antara lain, siswa belum mampu membaca, belum memahami operasi perhitungan dengan baik, kurang disiplin dalam mengerjakan soal, minat yang rendah dalam membaca soal secara intens. Tujuan penelitian untuk mendeskripsikan bagaimana penggunaan literasi matematika pada penyelesaian soal cerita.Metode penelitian yang digunakan adalah metode kualitatif-deskriptif dan bentuk penelitiannya adalah deskriptif.Teknik pengumpulan data menggunakanteknik tes, teknik observasi, dan teknik wawancara.Alat pengumpulan data menggunakan soal tes, lembar observasi, dan lembar wawancara. Hasil penelitian menunjukkan bahwa hanya ada 1 dari 16 siswa memiliki nilai 51 dengan kategori predikat nilai $C$ (cukup) dan 15 orang yang berkemampuan rendah dengan rata-rata nilai 9,5 kategori D (kurang), secara keseluruhan nilai rata-rata siswa kelas VA pada penyelesaian soal cerita adalah 12 dengan predikat D (kurang) oleh karena itu penggunaan literasi matematika pada penyelesaian soal cerita masih tergolong rendah. Literasi matematika pada penyelesaian soal cerita di kelas VA SDN 6 Sintang tahun pelajaran 2019/2020 masih rendah karena rendahnya kemampuan membaca, menulis dan kemampuan numerik, serta peran guru dan sekolah yang kurang mendukung dalam pembelajaran literasi matematika.
\end{abstract}

Kata Kunci: Literasi, Matematika, Penyelesaian, dan Soal Cerita 


\section{PENDAHULUAN}

Pendidikan yakni suatu proses pembelajaran yang terencana dan secara sadar dilakukan untuk mewujudkan taraf hidup manusia. Pendidikan merupakan suatu usaha untuk mengembangkan manusia atau memanusiakan manusia (Sinson dan Wedyawati, 2017: 23). Pentingnya pendidikan ditinjau dari segala aspek, yaitu aspek sosial, politik, ekonomi, budaya, dan lain sebagainya."Bagi kehidupan umat manusia, pendidikan merupakan kebutuhan mutlak yang harus dipenuhi sepanjang hayat (Mahfud 2016: 33). Menurut Mafud tanpa pendidikan, maka mustahil suatu kelompok untuk hidup dan berkembang. Pendidikan mencakup bagaimana proses belajar dan pembelajaran yang umumnya didapatkan di jenjang pendidikan TK, SD, SMP, SMA/SMK, dan PT (Perguruan Tinggi).

Proses pengembangan belajar dan pembelajaran siswa didukung melalui pengajaran materi dasar yang dipelajari di kelas rendah yaitu mengenai kemampuan membaca, menulis dan berhitung. Hal ini sesuai dengan pembelajaran multiliterasi siswa yang diharapkan mampu dikembangkan bukan hanya dari segi akademis tetapi juga diimplementasikan dalam kehidupan seharihari. Multiliterasi yaitu, pola baru dalam pembelajaran literasi."Konsep multiliterasi muncul karena manusia tidak hanya membaca atau menulis, namun mereka membaca dan menulis dengan genre tertentu yang melibatkan tujuan sosial, kultural, dan politik yang menjadi tuntutan era globalisasi, maka hal ini menjadi dasar lahirnya multiliterasi dalam dunia pendidikan." (Dafit, 2017: 51).

Pembelajaran literasi dibentuk dalam keterkaitannya dengan konsep multiliterasi memiliki kesesuaian.Literasi dan multiliterasi sama-sama mempunyai konsep bahwa pengembangan kemampuan membaca dan menulis, adalah hal yang paling dasar dan sederhana untuk dipahami. Hubungan keduanya juga tentang kemampuan berpikir kritis dalam mengembangkan ide-ide sesuai tuntutan zaman. Dafit (2017: 51) multiliterasi adalah pembelajaran yang senantiasa menggunakan keterampilan berbahasa untuk mempelajari dan membentuk pemahaman yang kompleks atas pengetahuan yang berhubungan dengan ilmu lainnya dalam proses kegiatan inkuiri serta sebagai sarana membangun pengetahuan. Konsep multiliterasi menawarkan agar siswa memperluas wawasan mengenai beragam wacana, isu-isu, serta fakta-fakta menarik yang bersumber dari lebih dari satu disiplin ilmu (sastra, IPA, IPS, matematika, dan lain sebagainya) dan menerapkan pembelajaran multiliterasi di sekolah dalam kurikulum integratif dipandang sangat tepat dan relevan.Selain itu, pembelajaran literasi juga terkait penggunaan media, alat, serta teknologi yang digunakan untuk mendapatkan suatu inforrmasi dalam hal pembelajaran.

Sesuai kaitannya dengan multiliterasi manfaat dari memiliki kemampuan literasi yang baik adalah siswa dapat lebih memahami apa yang dibaca dan yang ditulis tetapi juga dapat menyerap informasi yang ada dalam 
suatu bacaan dengan baik dan terintegrasi, sehingga siswa juga dapat memberi tanggapan terhadap informasi yang diterimanya secara kritis. Sejalan dengan pendapat Kharizmi (2015: 13) mengemukakan bahwa "literasi dalam bentuk yang fundamental mengadung pengertian kemampuan membaca, menulis dan berpikir kritis." Pada sekolah menengah pembelajaran literasi diharapkan perkembangan kemampuan literasi siswa sudah pada level meningkat yaitu siswa sudah pada tingkat dimana sudah bisa mengenal dan memanfaatkan teknologi dan berbagai bacaan yang akan menstimulasi mereka dalam mengembangkan kemampuan komunikasi, yang kritis, aktif, dan kreatif di masa depan. Abidin, dkk. (2018: 24) mengatakan bahwa sepanjang pembelajaran, siswa dituntut untuk selalu mengembangkan dan menyempurnakan kemampuannya dalam menciptakan berbagai jenis teks, melalui berbagai pemanfaatan teknologi dan konteks secara baik. Dengan kata lain, literasi juga berhubungan dengan penggunaan media-media untuk menerapkan ilmu itu sendiri.

Ojose mengutarakan "Hakikat literasi matematika adalah siswa mampu menggunakan pengetahuan dan kompetensi dasar dalam matematika yang dipelajari untuk digunakan secara percaya diri dalam menyelesaikan persoalan dalam konteks kehidupan sehari-hari” dalam Nurkamilah, dkk. (2018: 72).Oleh karena itu, dapat disimpulkan bahwa tepat apabila literasi matematika mulai diperkenalkan dan dikembangkan sejak pendidikan dasar. Oleh karena itu peneliti memilih kelas $\mathrm{V}$ sebagai objek penelitian karena kemampuan membaca, menulis, serta mengitung dianggap sudah cukup untuk menyisipkan pengembangan pembelajaran literasi matematika. Menurut Indah, dkk. (2011: 201), literasi matematika merupakan sebuah pengetahuan untuk mengetahui dan menerapkan dasar matematika dalam kehidupan sehari-hari. Literasi matematika diharapkan mampu untuk memberi kemudahan bagi siswa memahami berbagai masalah matematis. Literasi matematika yaitu kemampuan untuk mengintervensi masalah matematis secara kontekstual, yang berarti masalah matematika berkaitan langsung dengan kehidupan seharihari dan nyata melalui berbagai media, teknologi baik secara konvensional (contohnya buku cetak, media gambar, benda- benda yang terdapat di lingkungan sekitar, simulasi dan demonstrasi suatu hal di depan kelas oleh guru, metode ceramah yang dipakai guru dan lainnya) maupun secara modern (penggunaan komputer, gadget, internet, aplikasi otomatis dan sebagainya). Abidin dkk. (2018:111), menafsirkan bahwa "menjadi sulit bagi sebagian siswa untuk menyelesaikan soal cerita, apalagi pada soal pemecahan masalah, dikarenakan siswa belum memahami masalah yang terdapat dalam soal, siswa sekadar membaca tanpa memahami. "Soal cerita matematika sangat berperan dalam kehidupan sehari-hari siswa karena soal tersebut mengedepankan permasalahan-permasalahan yang sesuai dengan kehidupan sehari-hari, serta soal cerita sebagai bentuk evaluasi kemampuan siswa terhadap konsep dasar matematika yang telah dipelajari (Wahyuddin, 
2016:151). Urgensi dalam penelitian ini adalah menganalisis kemampuan literasi matematika dan mengembangkan keterampilan literasi matematika yang kelak berguna bagi siswa dalam bermasyarakat dan bidang lainnya pada kehidupan masa depan siswa. Penguasaan literasi matematika bagi siswa juga akan menghasilkan pembelajaran matematika yang baik dan berkualitas bagi guru dalam proses pembelajaran.

Siswa yang belum bisa membaca dan berhitung cenderung memiliki kemampuan literasi matematis yang kurang, karena literasi matematika berdasar pada literasi membaca, menulis, dan berhitung, Kharizmi, M. (2015). Berbagai masalah tersebut berimplikasi dengan ketidakmampuan siswa dalam berpikir kritis untuk memahami apa yang dibaca dan ditulis khususnya dalam penyelesaian soal cerita matematika.

Permasalahan lainnya yang sering dijumpai dilapangan adalah pendidikan guru mata pelajaran matematika (guru honorer) di kelas VA yang bukan berlatar belakang dari jurusan atau fakultas pendidikan keguruan atau pendidikan bidang matematika melainkan dari jurusan lain yaitu ilmu hukum (sarjana hukum) tentu jauh dari bidang yang ia tangani di lingkungan belajar siswa, khususnya dalam mata pelajaran matematika. Guru tidak belajar mengenai matematika secara luas termasuk mempelajari literasi matematika. Guru yang kurang maksimal menggunakan bahan ajar dan media-media belajar juga menjadi salah satu penyebab siswa mengalami kesulitan untuk pembelajaran literasi matematika.Rendahnya kemampuan literasi matematika siswa dipengaruhi oleh kurangnya partisipasi sekoah dalam menunjang keaktifan siswa dalam hal literasi khususnya literasi matematika. Contoh konkritnya adalah tidak program literasi matematika yang dibuat sekolah baik di kelas maupun diliar jam pelajaran, tidak adanya kegiatan.

Berdasarkan kajian pada penelitan terdahulu, maka tujuanumum penelitian yaitu menganalisis sejauh mana pemahaman siswa menyelesaikan soal cerita dalam hal literasi matematika siswa sesuai dengan materi yang mereka pelajari. Tujuan khusus penelitian adalah: Pertama, mengetahui penggunaan literasi matematika pada penyelesaian soal cerita. Kedua, mengetahui urgensi literasi matematika pada penyelesaian soal cerita di kelas dan. Ketiga, mengetahui penyediaan pendukung adanya literasi matematika pada penyelesaian soal cerita.

\section{METODE}

Metode yang digunakan dalam penelitian ini adalah metode kualitatifdeskriptif.Subjek dalam penelitian ini adalah siswa kelas VA, guru serta kepala sekolah SDN 6 Sintang.Objek dalam penelitian ini adalah literasi matematika dan soal cerita yang dillihat pada siswa yang akan di tarik kesimpulannya oleh peneliti. Alat pengumpul data dalam penelitian ini adalah soal tes,lembar observasi, panduan wawancara. Teknik pengumpulan data dalam penelitian ini adalah yang digunakan menurut Sukmadinata dalam Wedyawati, (2015: 146) ada 4 teknik pengumpulan data yang dapat digunakan yaitu 
wawancara, angket, observasi, dan studi dokumenter. Namun dalam penelitian ini peneliti hanya menggunakan 2 teknik ditambah dengan teknik tes yaitu tes soal cerita matematika.

\section{HASIL DAN PEMBAHASAN}

Hasil tes yang diperoleh merupakan jawaban dari 16 siswa yang mana seluruh siswa kelas VA berjumlah 19 orang. Pada pelaksanaan tes tidak semua siswa ikut mengerjakan soal karena ada 2 siswa yang melaksanakan kegiatan latihan sebagai peserta lomba dalam memperingati HUT RI ke-74 pada 6 Agustus 2019 lalu, dan satu orang siswa tidak hadir dengan alasan sakit.

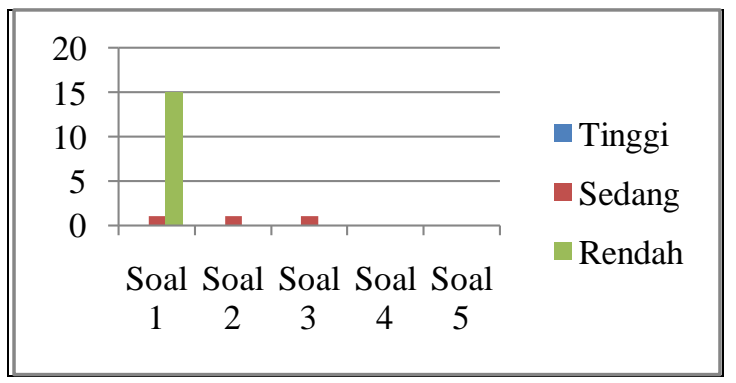

\section{Gambar 1 Diagram Hasil Tes Soal Cerita Berbentuk Literasi Matematika}

Diagram hasil tes menunjukkan bahwa siswa mengalami kesulitan menyelesaikan soal cerita matematis, pada soal pertama didominasi dengan hasil banyaknya siswa mengalami kesulitan terbanyak. Soal kedua dan soal ketiga menghasilkan kemampuan menyelesaikan cerita matematis pada level rendah. Hasil pada soal ke empat dan ke lima menunjukkan siswa sama sekali belum mampu menyelesaikan soal. Hasil ini menunjukkan bahwa siswa belum memiliki pemahaman dan wawasan tentang literasi matematika yang masih minim. Saragih \& Wedyawati, (2019: 15) Pengetahuanadalah hasil ingatan yang berpengaruh terhadappemahaman hal ini terjadi ketika peserta didik harus belajar.

Tabel 1 Tabel interval dan kategori nlai penyelesaian soal cerita matematika.

\begin{tabular}{lll}
\hline Interval Predikat & Predikat & Keterangan \\
\hline $84-100$ & A & Sangat Baik \\
\hline $66-84$ & B & Baik \\
\hline $50-66$ & C & Cukup \\
\hline$<50$ & D & Kurang \\
\hline
\end{tabular}

Adapun dari hasil penelitian dapat dilihat bahwa siswa secara keseluruhan belum mampu menyelesaikan masalah secara matematis. Hanya ada 1 dari 16 siswa yang dapat dikategorikan memiliki kemampuan penggunaan kemampuan literasi matematika yang cukup atau kategori predikat C, sedangkan sisanya ada 15 siswa yang berkemampuan rendah dengan kategori predikat D (kurang). Diketahui bahwa tingkat kemampuan literasi matematika pada penyelesaian soal cerita dikategorikan dengan nilai D (kurang) dengan perolehan nilai ratarata yaitu 12 .

Hasil wawancara menunjukkan bahwa siswa berkemampuan tinggi dan sedang mampu memenuhi aspek komunikasi, matematisasi, representasi, penalaran, kemampuan memecahkan masalah, dan menggunakan simbol serta alat atau mediamedia yang membantu memahami permasalahan dalam soal cerita, sedangkan siswa berkemampuan rendah tidak menjawab pertanyaan wawancara sesuai yang diinginkan dan tidak menguasai aspek-aspek kemampuan literasi matematika secara baik. Sesuai akumulasi mengenai jumlah siswa sesuai 
kemampuannya, maka siswa yang berkemampuan rendah masih mendominasi di kelas VA, dan dapat disimpulkan bahwa penggunaan literasi matematika di kelas VA masih tergolong sangat rendah karena lebih dari setengah jumlah siswa masih memiliki kemampuan literasi matematika yang rendah khususnya pada penyelesaian soal cerita.

\section{SIMPULAN (PENUTUP)}

Penggunaan literasi matematika pada penyelesaian soal cerita masih tergolong rendah.Adapun dari hasil penelitian dapat dilihat bahwa siswa secara keseluruhan belum mampu menyelesaikan masalah secara matematis.Urgensi literasi matematika pada penyelesaian soal cerita di SDN 6 Sintang khususnya di kelas VA belum menjadi suatu konsep yang menjadi perhatian.Jadi, jika dilihat secara menyeluruh literasi matematika bukan menjadi urgensi yang diutamakan. Penyediaan pendukung adanya literasi matematika pada penyelesaian soal cerita tergolong standar.

Khususnya siswa kelas tinggi seharusnya telah mampu memenuhi kemampuan membaca, menulis dan berhitung, agar mampu menyesuaikan pemahamannya dengan konsep pembelajaran literasi matematika.Guruseharusnya mulai membelajarkan literasi matematika secara dasar khususnya di kelas tinggi.

\section{DAFTAR PUSTAKA}

Abidin, Y. dkk. 2018. Pembelajaran Literasi. Jakarta: Bumi Aksara.

Dafit, F. 2017. Keefektifan Kemampuan
Menulis Kreatif Siswa SD dengan Model Pembelajaran Multiliterasi ".GERAM (Gerakan Aktif Menulis). 5(1):49-57.

Indah, N., dkk. 2016. Peningkatan Kemampuan Literasi Matematika Siswa Melalui Penerapan Model Pembelajaran Problem Based Learning Di Kelas VII SMP Negeri 5 Pallangga Kabupaten Gowa. Jurnal Matematika dan Pelajaran, 4(2): 198210.

Kharizmi, M. 2015. Kesulitan Siswa Sekolah Dasar dalam Meningkatkan Kemampuan Literasi. JUPENDAS, 2(2):11-21.

Mahfud, C. 2016. Pendidikan Multikultural. Yogyakarta: Pustaka Pelajar.

Nurkamilah, dkk. 2018. Mengembangkan Literasi Matematika Siswa Sekolah Dasar melalui Pembelajaran Matematika Realistik Indonesia. Jurnal THEOREMS (The Original Research of Mathematics), 2(2):70-79.

Saragih, E., dan Wedyawati, N., 2019. Penerapan Model Pembelajaran TGT untuk Peningkatan Hasil Belajar Materi Bilangan Romawi siswa kelas IV Sekolah Dasar. Jurnal RIEMANN, Research of Mathematics and Mathematics Education, 1(1): 14-24.

Sinson, M., dan Wedyawati, N., 2017. Analisis Sikap Belajar Siswa Kelas Tinggi Pada Mata Pelajaran Ilmu Pengetahuan Alam (IPA). Jurnal VOX Edukasi, 8(1): 22-29.

Wahyuddin. 2016. Analisis Kemampuan Menyelesaikan Soal Cerita Matematika Ditinjau Dari Kemampuan Verbal. Jurnal Tradis Matematika, 9(2): 148-160

Wedyawati. N.,2015. Deskripsi Analisis Keterampilan Variasi Mengajar Guru IPA di Sekolah Dasar Negeri 12 Jerora Sintang. Jurnal VOX Edukasi, 6(2):143-155. 